COMPETITOR: Jurnal Pendidikan Kepelatihan Olahraga

Volume 13 Number 2 Year 2021

e-ISSN: 2657-0734 \& p-ISSN: 2085-5389

This work is licensed under a Creative Commons Attribution 4.0 International License

\title{
Development of the Gyaku Tsuki and Mawashi Geri Speed Test
}

\author{
Suprianto Kadir ${ }^{1}$, Arief Ibnu Haryanto ${ }^{2^{*}}$ \\ ${ }^{1}$ Department of Sports Coaching Education, Faculty of Sports and Health, \\ Gorontalo State University \\ ${ }^{1}$ Tanggikiki Village, Sipatana District, Gorontalo City, Gorontalo Province, Indonesia \\ ${ }^{2}$ Sport Science Study Program, Faculty of Teacher Training and Education, \\ Muhammadiyah University of Gorontalo \\ ${ }^{2}$ Street. Prof. Dr. H. Mansoer Pateda, East Pentadio Village, Telaga Biru District, Gorontalo Regency, \\ Gorontalo Province, Indonesia \\ ${ }^{1}$ suprianto.kadir@ung.ac.id, ${ }^{2}$ ariefibnu67@gmail.com
}

Received: February 23, 2021; Reviewed: April 12, 2021; Accepted: 25 April 2021; Published: June 18, 2021

\begin{abstract}
This study aims to develop a speed test for Gyaku Tsuki and Mawashi Geri kicks in Karate. This research is development research with steps that include potential problems, data, product design, design validation, revision design, product testing, product revision, trial use and product revision. The small scale trial was carried out on 10 Karateka who actively participate in the training at the PPLP Gorontalo Province. Meanwhile, a large-scale trial was conducted on 30 Karateka who took part in the training at the PPLP Gorontalo Province. The development research resulted in a valid and reliable form of test, so it was feasible to use it to measure the speed of the Gyaku Tsuki shot and the kick speed of Mawashi Geri.
\end{abstract}

Keywords: Speed Test; Gyaku Tsuki; Mawashi Geri.

\section{INTRODUCTION}

Karate is one of the branches of martial arts that has become worldwide and is growing rapidly in almost all circles of society, including in Gorontalo Province (Kadir, 2020). This can be seen from the many Dojos (Karate training places) and coaching and Karate events held in Gorontalo Province. Two types of categories compete in Karate, namely Kata (demonstrations) and Kumite (matches) (Coy et al., 2019). Especially in the Kumite category, to support good performance during matches, an athlete should have the good physical condition (Franchini et al., 2009) and be able to apply various forms of Kumite techniques well (Koropanovski et al., 2011).

Karate in the Kumite category is a competitive sport (Hardinoto et al., 2017). The dominant physical condition in Kumite is muscle explosive power in Karateka capacity 
Development of the Gyaku Tsuki and Mawashi Geri Speed Test

Suprianto Kadir, Arief Ibnu Haryanto

ariefibnu67@gmail.com

for high-level performance (Chaabène et al., 2012). The high metabolism of Karateka in the Kumite category also implies that Kumite has dominant energy in aerobics (Beneke et al., 2004) and has a higher level of aggressiveness than Kata (Piepiora et al., 2016).

Related to the Kumite technique that is often used during matches in several official Karate matches, namely the World Championships in Madrid 2002, Monte Ray 2004, European Championships in Bremen 2003, Moscow 2004, Tenerife 2005, and Finland 2006. Based on the results of observations and analysis conducted on the championship in question, obtained results related to attack technique activities carried out by athletes during competition. In general, it is the basic techniques of punches and kicks that earn points in Kumite (Koropanovski et al., 2008) (Marandi et al., 2010).

The results of this analysis, in turn, provide an understanding that almost all points in Kumite matches are obtained from various attack techniques, namely hitting techniques (Matutu et al., 2019) and kicks (Wanda et al., 2018). Thus, the technical aspects that have been analyzed most dominantly appear in the above championships, the coaches should also pay attention to their improvement (Jukić et al., 2013).

The success of Karate athletes in using various Kumite techniques cannot be separated from the contribution of the components of supporting physical conditions (Bussweiler \& Hartmann, 2012) and techniques (Liu et al., 2016). Seeing movement patterns in Kumite matches, especially when launching attack techniques, are generally carried out with maximum speed and the right timing (Syaquro et al., 2017). In response to this, a valid and reliable form of test is needed to determine the speed of punches and kicks in Karate.

The reality in the field is related to measuring the speed of punches and kicks in Karate which has an accurate level of validity and reliability, until now it is still difficult to find. The previous research focused on the development of the Mawashi Geri kick speed test instrument in the Karate sport (Simbolon \& Siahaan, 2020), which is different from this research.

In response to this, the researcher feels the need to create a valid and reliable measuring tool for the speed of punches and kicks in Karate, which can later be used as one of the test and measurement instruments by related parties. Given the complexity of the punches and kicks in Karate as described above, on this occasion the development of the test for the speed of punches and kicks in Karate in question is limited to the speed of Gyaku Tsuki and Mawashi Geri because these two techniques based on the observations of researchers are often used in current matches. 
Development of the Gyaku Tsuki and Mawashi Geri Speed Test

Suprianto Kadir, Arief Ibnu Haryanto

ariefibnu67@gmail.com

\section{METHOD}

This study aims to create a test model for the speed of Gyaku Tsuki's punches and Mawashi Geri's kicks in Karate, especially the Kumite category. The method used in this research is the research and development method. This type of research and development research was chosen because it is product-oriented. In this study, the orientation is to find an instrument that can be used to test the speed of Gyaku Tsuki's punches and Mawashi Geri's kicks which at this time are still difficult to find.

This research was conducted at the Pusat Pendidikan dan Latihan Pelajar (PPLP) of Gorontalo Province which was carried out for 6 months starting from April 2020 to October 2020 with strict attention to health protocols. The population in this study were all Karate athletes who took part in training at the Pusat Pendidikan dan Latihan Pelajar (PPLP) of Gorontalo Province, totalling 30 people. The sample in this study amounted to 10 people obtained from the use of purposive sampling method with the following criteria: active karateka in joint training at PPLP Gorontalo Province; Karateka in Kumite category/number; Karateka at kyu 3 - kyu 1 belt level; and Karateka who can perform Gyaku Tsuki punches and Mawashi Geri kicks.

This research and development procedure uses 9 steps which include: potential problems, data collection, product design, design validation, design revisions, product trials, product revisions, usage trials and product revisions (Sugiyono, 2017).

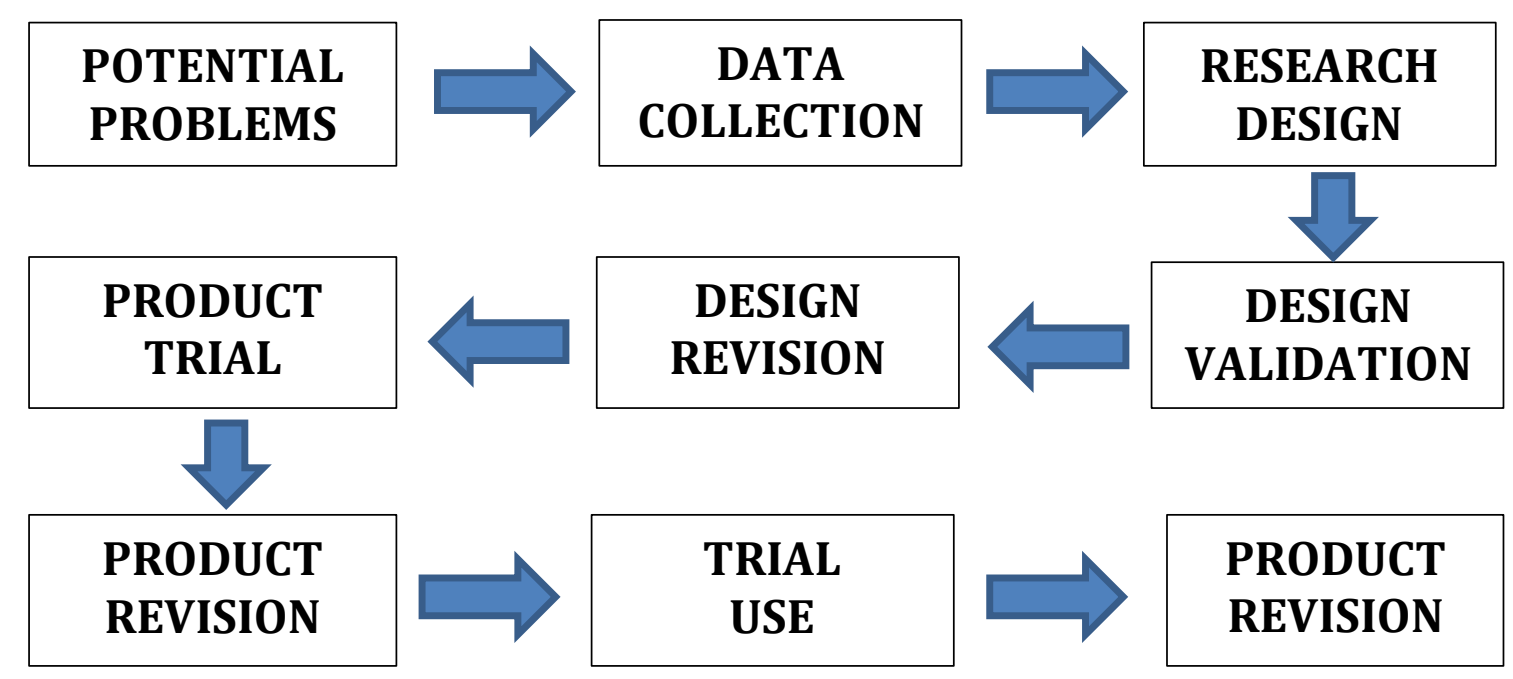

Picture 1.

Development Research Procedure (Sugiyono, 2017)

Before the product development in this study was tested, validation was requested from the appointed experts. After the product design is revised and approved by experts, 
then the product will be tested in the field. The product trial designs are as follows:

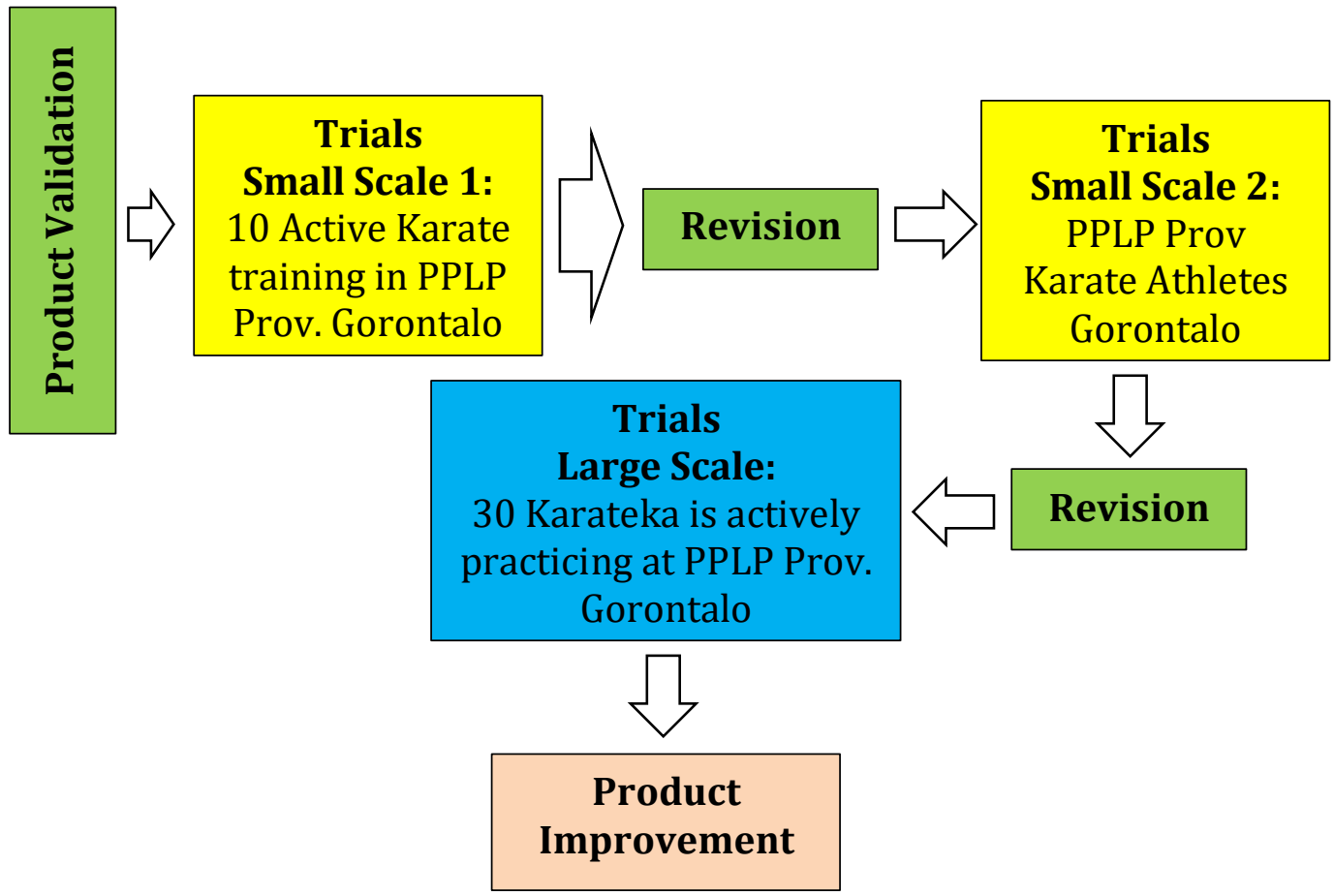

Figure 2.

Product Trial Design

The instrument in this study was a test model of Gyaku Tsuki's punch speed and Mawashi Geri's kick which was compiled by the researcher and approved by a team of experts. The team of experts selected are experts in Karate, motion biomechanics in sports and experts in sports testing and measurement. The data obtained in this research and development are in the form of qualitative and quantitative data. Qualitative data comes from the results of trainer interviews, lack of test models from experts and experts and material input from experts related to the form of the test. The quantitative data were obtained from expert assessments of product drafts, observation sheets of trainers, experts and experts and product effectiveness sheets. All the data obtained were used to evaluate the speed test of Gyaku Tsuki's punches and Mawashi Geri's kicks in Karate. Referring to the type of data, the data collection instruments used were interviews and questionnaires.

To find out the results of the research carried out, data analysis techniques are needed. The data obtained will be divided into 2 parts, namely qualitative data which are suggestions and criticisms from experts which will then be processed into quantitative data. The analysis technique used for quantitative data is the descriptive statistical analysis technique which includes validity and reliability tests.

Validity testing is carried out to determine the level of validity of the questionnaire 
data given to expert judgment. This is done to determine the feasibility of the instrument to be tested. The questionnaire given to the expert is in the form of several questions that refer to the Guttman scale with the answer "YES" or "NO". If the validation process is close to $100 \%$ agreeing, then the research instrument is declared valid.

Reliability testing was carried out to see the consistency of the measurement results on subjects with the same measuring instrument. The reliability test uses the Pearson product-moment correlation with the following formula:

$$
\text { Formula }: r=\frac{\sum X Y}{\left.\sqrt{(} \sum X^{2}\right)\left(\sum Y^{2}\right)}
$$

Figure 3.

Pearson correlation formula product-moment (Usman \& Akbar, 2006)

Table 1.

Interpretation of r Value (Usman \& Akbar, 2006)

\begin{tabular}{cc}
\hline Score $\mathbf{r}$ & Interpretation \\
\hline 0 & Uncorrelated \\
$0,01-0,20$ & Very low \\
$0,21-0,40$ & Low \\
$0,41-0,60$ & Slightly Low \\
$0,61-0,80$ & Enough \\
$0,80-0,99$ & High \\
1 & Very high \\
\hline
\end{tabular}

\section{RESULTS AND DISCUSSION}

This research and development procedure uses rules that include: potential problems, data collection, product design, design validation, design revisions, product trials, product revisions, usage trials and product revisions (Sugiyono, 2017).

\section{Small-Group Trial}

Based on the sampling technique used in this study, the number of samples used for product trials in the form of Gyaku Tsuki's speed test and Mawashi Geri's kicks were obtained in a small group, which consisted of 10 Karateka who actively participated in training at PPLP Gorontalo Province. The implementation of small-scale product trials in this study was carried out by direct application of the product developed in the study to a predetermined sample.

The trial of the Gyaku Tsuki punch speed test product on a small scale can be summarized statistically as follows: 
Table 2.

Test Results of Gyaku Tsuki's Punch Speed Test in Small Groups

\begin{tabular}{lccc} 
& Statistics & Test $\mathbf{1}$ & Test $\mathbf{2}$ \\
\hline Sample & 10 & 10 \\
Average & 17,7 & 20,8 \\
Maximum & 19 & 23 \\
Minimum & 16 & 19 \\
\hline
\end{tabular}

Furthermore, a reliability test was conducted using the Pearson correlation of moment products to test whether the product of the Gyaku Tsuki punch speed test has the consistency of measurement results on subjects with the same measuring instrument. This is done so that later before the product is tested on a large group, it has a good level of validity and reliability as follows:

$$
r=\frac{\sum X Y}{\sqrt{\left(\sum X^{2}\right)\left(\sum Y^{2}\right)}}=\frac{10,52}{11,72}=0,897
$$

Based on the results of the reliability calculation and looking at the interpretation of the $r$ value, it can be concluded that the product of the Gyaku Tsuki punch speed test form used in small groups is declared reliable with a high interpretation.

Meanwhile, the trial of Mawashi Geri's kick speed test product on a small scale can be summarized statistically as follows:

Table 3.

Test Results of Mawashi Geri's Kick Speed Test in Small Groups

\begin{tabular}{|c|c|c|}
\hline Statistics & Test 1 & Test 2 \\
\hline Sample & 10 & 10 \\
\hline Average & 10,7 & 12,3 \\
\hline Maximum & 13 & 15 \\
\hline Minimum & 9 & 11 \\
\hline
\end{tabular}

Furthermore, a reliability test was carried out using the Pearson correlation of moment products to test whether the product of the Mawashi Geri kick speed test has the consistency of measurement results on subjects with the same measuring instrument. This is done so that later before the product is tested on a large group, it has a good level of validity and reliability as follows:

$$
r=\frac{\sum X Y}{\sqrt{\left(\sum X^{2}\right)\left(\sum Y^{2}\right)}}=\frac{14,04}{15,06}=0,932
$$

Based on the results of the reliability calculation and looking at the interpretation of the $r$ value, it can be concluded that the product of the Mawashi Geri kick speed test form used in small groups is declared reliable with a high interpretation. 
Development of the Gyaku Tsuki and Mawashi Geri Speed Test

Suprianto Kadir, Arief Ibnu Haryanto

ariefibnu67@gmail.com

\section{Large Group Trial}

Referring to the results of product trials that have been carried out by researchers in small groups, furthermore, the expert said that the product of the Gyaku Tsuki punches speed test and Mawashi Geri kicks have met the feasibility based on the validity and reliability tests that have been carried out, then the next product development test form in This research will be piloted in a large group.

The product trial activity in this large group was carried out on all Karateka who actively participated in joint training activities at PPLP Gorontalo Province, totalling 30 people, with the following results:

Table 4.

Test Results of Gyaku Tsuki's Punch Speed Test in Large Groups

\begin{tabular}{|c|c|c|}
\hline Statistics & Test 1 & Test 2 \\
\hline Sampel & 30 & 30 \\
\hline Rerata & 17,50 & 20,13 \\
\hline Maksimal & 19 & 23 \\
\hline Minimal & 15 & 17 \\
\hline
\end{tabular}

Furthermore, to test whether the product of the Gyaku Tsuki punch speed test has the consistency of measurement results on subjects with the same measuring instrument, by correlating the data in the first test with the data in the second test as follows:

$$
r=\frac{\sum X Y}{\sqrt{\left(\sum X^{2}\right)\left(\sum Y^{2}\right)}}=\frac{44,78}{51,95}=0,861
$$

Based on the results of the reliability calculation and looking at the interpretation of the $r$ value, it can be concluded that the product of the Gyaku Tsuki punch speed test form used in small groups is declared reliable with a high interpretation.

Table 5.

Test Results of Mawashi Geri's Kick Speed Test in Large Groups

\begin{tabular}{lccc} 
& Statistics & Tes $\mathbf{1}$ & Tes 2 \\
\hline Sampel & 30 & 30 \\
Rerata & 10,53 & 12,37 \\
Maksimal & 12 & 16 \\
Minimal & 8 & 10 \\
\hline
\end{tabular}

Furthermore, to test whether the product of the Mawashi Geri kick speed test has the consistency of measurement results on subjects with the same measuring instrument, by correlating the data in the first test with the data in the second test as follows: 


$$
r=\frac{\sum X Y}{\sqrt{\left(\sum X^{2}\right)\left(\sum Y^{2}\right)}}=\frac{46,28}{53,79}=0,860
$$

Based on the results of the reliability calculation and looking at the interpretation of the $r$ value, it can be concluded that the product of the Gyaku Tsuki punch speed test form used in small groups is declared reliable with a high interpretation.

\section{CONCLUSIONS AND SUGGESTIONS}

Referring to the results of the research that has been carried out, it can be concluded that the Gyaku Tsuki punch speed test model and Mawashi Geri kick speed test model were developed into one of the products in this research, can be used by all Karateka, especially athletes.

The form of the test produced in this study is suitable to be used to measure the speed of Gyaku Tsuki's punches and the speed of Mawashi Geri's kicks because they have passed the validation process of competent experts in their fields and have been tested and proven to have a high level of reliability.

By using this test model, it can be seen how far the level of Gyaku Tsuki's punch speed and Mawashi Geri tests kick speed is doing the test. Likewise, it can be said that, if the testee can make as many punches and kicks as possible following the existing test procedures, then this can show or describe his ability when participating in the match.

\section{REFERENCES}

Beneke, R., Beyer, T., Jachner, C., Erasmus, J., \& Hütler, M. (2004). Energetics of Karate Kumite. European Journal of Applied Physiology. https://doi.org/10.1007/s00421-004-1073-x

Bussweiler, J., \& Hartmann, U. (2012). Energetics of basic Karate Kata. European Journal of Applied Physiology. https://doi.org/10.1007/s00421-012-2383-z

Chaabène, H., Hachana, Y., Franchini, E., Mkaouer, B., \& Chamari, K. (2012). Physical and physiological profile of elite Karate athletes. In Sports Medicine. https://doi.org/10.2165/11633050-000000000-00000

Coy, J., Cree, J., \& Turner, A. (2019). Karate. In Routledge Handbook of Strength and Conditioning. https://doi.org/10.4324/9781315542393-20

Franchini, E., Sterkowicz, S., \& Franchini, E. (2009). Testing motor fitness in Karate. Archives of Budo.

Hardinoto, N., Syah, S., \& Sitepu, I. D. (2017). Perbedaan Karakter Olahraga Kompetitif. Jurnal Prestasi. 
Jukić, J., Katić, R., \& Bala, G. (2013). Morphological, motor and technical determinants of fighting efficiency of Croatian female cadet age Karate athletes. Collegium Antropologicum.

Kadir, S. (2020). Evaluation Of Vo2max Atlet Karate In The Covid-19 Pandemic Era. Jambura Journal of Sports Coaching. https://doi.org/10.37311/jjsc.v2i2.7058

Koropanovski, N., Berjan, B., Bozic, P. R., Pazin, N., Sanader, A., Jovanovic, S., \& Jaric, S. (2011). Anthropometric and physical performance profiles of elite Karate Kumite and kata competitors. Journal of Human Kinetics. https://doi.org/10.2478/v10078-011-0078-X

Koropanovski, N., Dopsaj, M., \& Jovanovic, S. (2008). Characteristics of Pointing Actions of Top Male Competitors in Karate at the World and European level. Brazilian Journal of Biomotoricity, 2(4), 241-251.

Liu, C., Jung, K., \& Shishida, F. (2016). Technical analysis of Seiryoku zen'yo Kokumin taiiku-from a Karate and Chinese martial arts perspective as it affected Kano Jigoro. Ido Movement for Culture. https://doi.org/10.14589/ido.16.1.1

Marandi, S. M., Zolaktaf, V., \& Batavani, M. R. (2010). Analyses of pointing actions of top male competitors in Karate at world level. British Journal of Sports Medicine. https://doi.org/10.1136/bjsm.2010.078725.174

Matutu, O. N., Nurliani, \& Fahrizal. (2019). Kontribusi Kecepatan Reaksi Tangan Dan Ketepatan Terhadap Kemampuan Pukulan Giaku Tsuki Pada Cabang Olahraga Karate Inkado Di Ranting Kota Makassar. Fakultas Ilmu Keolahragaan, Universitas Negeri Makassar.

Piepiora, P. A., Szmajke, A., Migasiewicz, J., \& Witkowski, K. (2016). The Karate culture and aggressiveness in Kumite competitors. Ido Movement for Culture. https://doi.org/10.14589/ido.16.2.5

Simbolon, R. F., \& Siahaan, D. (2020). Pengembangan Instrumen Tes Kecepatan Tendangan Mawashi Geri Pada Cabang Olahraga Karate. JURNAL PRESTASI. https://doi.org/10.24114/jp.v4i2.21585

Sugiyono. (2017). Metode Penelitian Kuantitatif, Kualitatif dan R\&D. Alfabeta.

Syaquro, A., Rusdiana, A., \& Sumardiyanto. (2017). Comparison of Whole Body Reaction and Anticipation Reaction Time between Kata and Kumite in Karate. IOP Conference Series: Materials Science and Engineering. https://doi.org/10.1088/1757899X/180/1/012232

Usman, H., \& Akbar, P. S. (2006). Pengantar Statistika. In Pengantar Statistika (2nd ed.). Bumi Aksara.

Wanda, D. F., Nurseto, F., \& Husin, S. (2018). Kontribusi Power Tungkai Dan Kecepatan Reaksi Terhadap Tendangan Mae Geri Pada Atlet Karate Putri. Jorpres (Jurnal Olahraga Prestasi). https://doi.org/10.21831/jorpres.v14i2.23828 